\title{
Histopathology of Red Stripe of Rice
}

\author{
Hisatoshi Kaku, National Institute of Agrobiological Sciences, Kannondai, Tsukuba, Ibaraki 305-8602, Japan
}

\begin{abstract}
Kaku, H. 2004. Histopathology of red stripe of rice. Plant Dis. 88:1304-1309.

A histological study of red stripe of rice was conducted to elucidate the mode of infection of the causal bacterium Microbacterium sp. When pin-point-sized spots first appeared at 3 days after inoculation, the bacterial cells had entered through stomata and multiplied in the intercellular spaces of substomatal parenchymatous tissues. With the early appearance of small yellow spots at 4 to 5 days after inoculation, the bacterium was detected in some xylem vessels as well as in parenchymatous tissues, and it had apparently translocated directly from parenchymatous tissues to transverse vascular systems through spiral vessel walls. With the appearance of typical red stripe symptoms comprised of orange lesions and halos at 8 days after inoculation, bacterial masses were present in transverse and longitudinal vascular bundles in areas with orange lesions. In the areas with orange to light brown spots, granules that stained dark blue using Stoughton's method appeared in the protoplasm of the host parenchymatous cells, which later became necrotic. In halo areas, bacterial masses were observed only in some cases, and chloroplasts were disorganized. Bacterial infection was also confirmed by observing sections of naturally infected samples, and the distribution of bacteria was much more extensive than in artificially inoculated samples.
\end{abstract}

Additional keywords: plant-pathogenic coryneform

Red stripe is a serious disease of rice (Oryza sativa) that has been spreading in intensive rice production areas of Southeast Asia within the last decade and has caused severe damage in rice production. In Vietnam, the total infected area was 64,200 ha in 1990, and increased to 199,000 ha in 1991 and is still spreading (19). The disease was first reported in Indonesia in 1988 (13). Since then, the disease has been reported in Malaysia, Vietnam, the Philippines, and Thailand $(2,12)$. Extensive research has been carried out in these countries with special reference to the causal agent of the disease.

In the first report on the disease, Mogi et al. (13) named it bacterial red stripe. Some bacteria have been isolated from the diseased rice plants in Indonesia and Vietnam $(12,13)$. However, pathogenicity of the bacteria has not been confirmed. Several fungal species have also been isolated from red stripe lesions, including Curvularia lunata and Nigrospora oryzae $(4,12)$. An unidentified fungus was also observed consistently on the lesions and was suspected as a pathogen (20). In addition, the

Corresponding author: H. Kaku

E-mail: hkaku@affrc.go.jp

Accepted for publication 14 May 2004.

Publication no. D-2004-0930-01R

() 2004 The American Phytopathological Society disease is thought by some researchers to be caused by a fungus because the disease can be controlled by spraying benzimidazole fungicides, especially benomyl and carbendazim (3). However, the fungicide has been shown to have antibacterial properties against the red stripe pathogen $\mathrm{Mi}$ crobacterium sp. (10).

Recently, the causal bacterium was isolated from diseased rice plants collected in Indonesia and identified as Microbacterium $\mathrm{sp}$. based on the sequence of $16 \mathrm{~S}$ rDNA (9,11). Although no plantpathogenic species has been reported from the genus Microbacterium, the family Microbacteriaceae includes some plant pathogens such as Clavibacter (1). An examination of the infection mode of the causal bacterium of red stripe should be conducted to determine if it is similar to pathogenic activities of Clavibacter.

Some histopathology of rice plants inoculated with Microbacterium by needlepricking was done to confirm bacterial multiplication and translocation in leaf tissues (11). The purpose of the present study was to observe histological changes in artificially inoculated rice plant tissues obtained by spray inoculation with Microbacterium sp. Specific goals were to examine the ingress and translocation of the causal bacterium and subsequent cytological changes in infected host tissues. In addition, ingress of the pathogen and histology of naturally occurring red stripe was examined in field-grown rice.

\section{MATERIALS AND METHODS}

Samples of artificially inoculated rice plant for histology. Seeds of the rice cultivar IR64 were sown in a nursery bed. Seedlings were transplanted to $12-\mathrm{cm}$ plastic pots filled with clay soil at 14 days after sowing (five plants per pot), and were grown in a greenhouse. At 60 days after sowing, plants were inoculated with strain RSB-1 of Microbacterium sp. Bacterial cultures were grown on peptone sucrose agar slants at $25^{\circ} \mathrm{C}$ for 2 days. Cultures for experiments were grown from lyophilized stock. They were subcultured once. The bacterial strain was grown on peptone sucrose agar slants for $48 \mathrm{~h}$ at $25^{\circ} \mathrm{C}$. The bacterial suspension was adjusted to a concentration of approximately $10^{8}$ $\mathrm{CFU} / \mathrm{ml}$ using a spectrophotometer. The bacterial suspensions were sprayed onto leaves using a hand-atomizer. The inoculated plants were covered with plastic bags and incubated for 2 days, and thereafter kept in an isolated greenhouse. Control plants were sprayed with sterile distilled water and were incubated using the same methods employed for inoculated plants. Leaf samples of early, middle, and late stages of symptom development were collected at 4, 8, and 12 days after inoculation, respectively. Samples of very early symptoms, mainly composed of transparent dots, were also harvested 3 days after inoculation. Leaf samples from control plants were also collected for histology.

Samples of rice naturally infected with red stripe for histology. Rice leaves with typical symptoms of naturally occurring red stripe were collected from farmers' paddy fields in Klaten, Sleman, and Yogyakarta, Indonesia, in 1998 and 1999. Most samples were taken from cultivars IR64 and Cisadane. Samples of typical early, middle, and late symptom development were also collected from the experimental paddy fields of Cuu Long Delta Rice Research Institute of Omon, Cantho in Vietnam. Leaf samples without symptoms were also taken from the same paddy fields where the diseased samples were collected and served as controls.

Histology. For histology, 12 samples of early, middle, and late symptoms, respectively, were examined. Tissues were also collected from the control plants.

The rice leaf tissues including the lesions were cut and fixed in formalin-acetoalcohol (FAA, No. 1 solution of $90 \mathrm{ml}$ of $70 \%$ ethanol, $5 \mathrm{ml}$ of formalin, and $5 \mathrm{ml}$ of 
glacial acetic acid) for 3 days or longer. The samples were soaked in a mixture of hydrofluoric acid and 70\% ethanol (1:2, $\mathrm{vol} / \mathrm{vol}$ ) for 1 week to soften the tissues, then rinsed in running tap water for 3 days or longer and dehydrated through an ethanol series. They were then embedded in Paraplast (Sherwood Medical Industries, St. Louis, MO) embedding medium mixed with $n$-butyl alcohol. Serial sections (15 $\mu \mathrm{m}$ thick) were cut on a Leitz 1516 rotarymicrotome (Ernst Leitz Wetzlar GMBH, Germany). The ribbons were mounted on clean slides with Mayer's adhesive. Sections were stained using Stoughton's double staining method (16).

All sections were examined with an Olympus BX50 microscope and photographed with a C-35AD-4 camera and Ektachrome EX125 film.

\section{RESULTS}

Symptoms. The symptoms of red stripe appeared on leaf blades or upper parts of leaf sheaths at the heading stage in the paddy fields. Red stripe symptoms were produced on rice seedlings via artificial inoculation.

A typical lesion consisted of an orange to reddish-brown spot with a long white halo that ran lengthwise from the spot to the leaf tip (Fig. 1A). In the very early stages of disease development, pin-pointsized, transparent to dark green spots were scattered on the surface of the leaf blade (Fig. 1B). Such dots were seen more clearly by holding the leaves up against a light source. Lesions had a water-soaked margin in early morning or in humid conditions. They enlarged and turned yellow, and yellow to orange stripes soon formed. Stripes were most often accompanied by a whitish halo along the leaf vein. Typical lesions of red stripe have a central area that becomes sunken and necrotic.

In the late stage of infection, the stripes elongated very rapidly toward the leaf tips. In severe case, the lesions spread extensively, and blight symptoms developed. Such leaves eventually became completely dry.

Histological observation of artificially inoculated samples. Stoughton's staining is a very efficient differential staining method used to detect bacteria and fungi on and in plant tissues. Bacteria and fungi are stained purple, while parenchymatous and suberized cells of the host plant are stained orange and blue, respectively.

In cross sections of the transparent, pinpoint-sized dots that appeared on the leaf blade at 3 days after inoculation, purple bacterial cells were detected as a mass in the intercellular spaces of parenchymatous tissues under stomata (Fig. 2A). Single bacterial cells were not distinguishable. The earliest response in host plant tissues was discoloration and degradation of the protoplasm of the parenchymatous cells in which the bacterial cells multiplied (Fig.
2A). After bacterial cells had multiplied to some extent, small globular granules that stained dark blue appeared in parenchymatous cells. They enlarged as cell degradation proceeded.

One of the most important aspects of infection is how the pathogen enters the host tissues. In the case of artificially inoculated samples, the bacterial cells entered rice leaf tissues through stomata. The bacterial cells were detected on the stomata as well as in substomatal cavities. After they entered the intercellular spaces of parenchymatous tissues, however, they multi- plied rapidly under the stomata and translocated through the intercellular spaces (Fig. 2A and B). After multiplication of the bacterial cells in the intercellular spaces of parenchyma, they translocated from parenchymatous tissues to xylem vessels through spiral vessel walls (Fig. 2D).

In sections of the orange spots with halos that appeared at 8 days after inoculation, the bacterial masses were observed in the xylem vessels of vascular bundles in all the samples examined (Fig. 2C). Bacterial masses were observed more frequently in the transverse vascular bundles (connecting
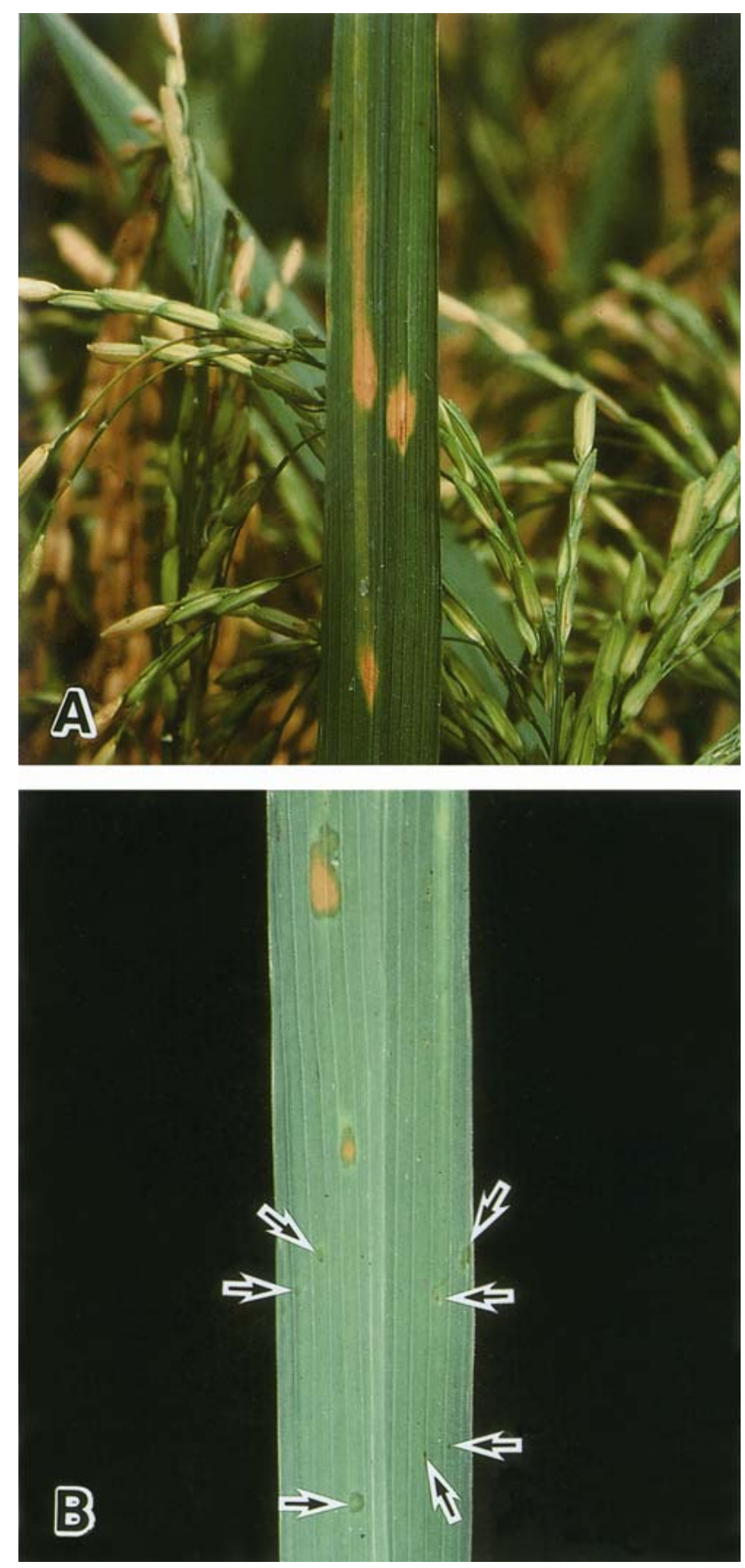

Fig. 1. Symptoms of red stripe of rice. A, Typical symptoms of red stripe composed of orange spots with long halos running lengthwise from the spot toward the leaf tip. B, Early symptoms of red stripe. Pin-point-sized dots on rice leaves are transparent to dark green (arrows). Dots expand and become small orange spots as the disease progresses. 

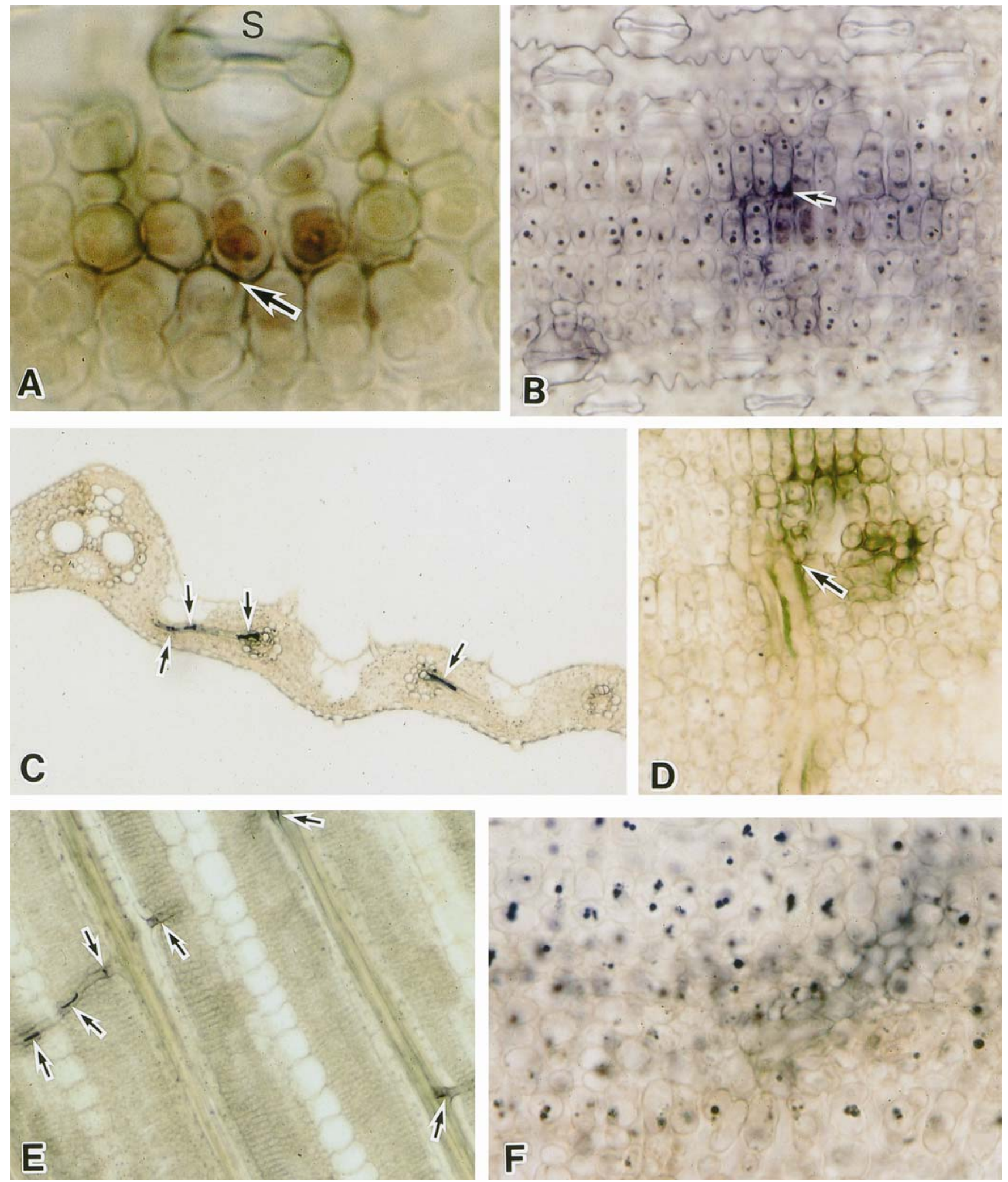

Fig. 2. Histopathology of red stripe on rice leaves after artificial inoculation of plants. A, Cross section through very-early-developing, pin-point-sized spot. Bacterial masses (arrow) are observed in the intercellular spaces between parenchymatous cells under stoma (S). Protoplasm of these host cells is discolored and degenerated $(\times 1,675)$. B, Cross section of early-developing orange spot. In the infected parenchymatous tissues, round granules in the protoplasm are stained dark blue. Protoplasm of parenchymatous cells with surrounding bacterial masses (arrow) is discolored and degenerated ( $\times 835$ ). $\mathbf{C}$, Cross section of typical orange spot. Bacterial masses (arrows) are detected as purple clusters in transverse xylem vessels (connecting strands) connected to longitudinal vascular bundle in area of orange spot $(\times 105)$. D, Cross section of leaf with bacterial masses in xylem vessel. Arrow indicates where bacterial mass translocated from parenchymatous tissues through vessel wall into transverse xylem vessels (connecting strand) $(\times 750)$. E, Longitudinal section parallel to leaf surface with bacterial masses distributed in vascular system of area of orange lesion $(\times 125)$. Bacterial masses (arrows) are localized in the transverse xylem vessels, especially those adjacent to longitudinal vascular bundle. F, Longitudinal section through area of blight symptom on leaf. Parechymatous tissues are composed of cells containing small granules stained dark blue or cells with degenerated protoplasm $(\times 850)$. 

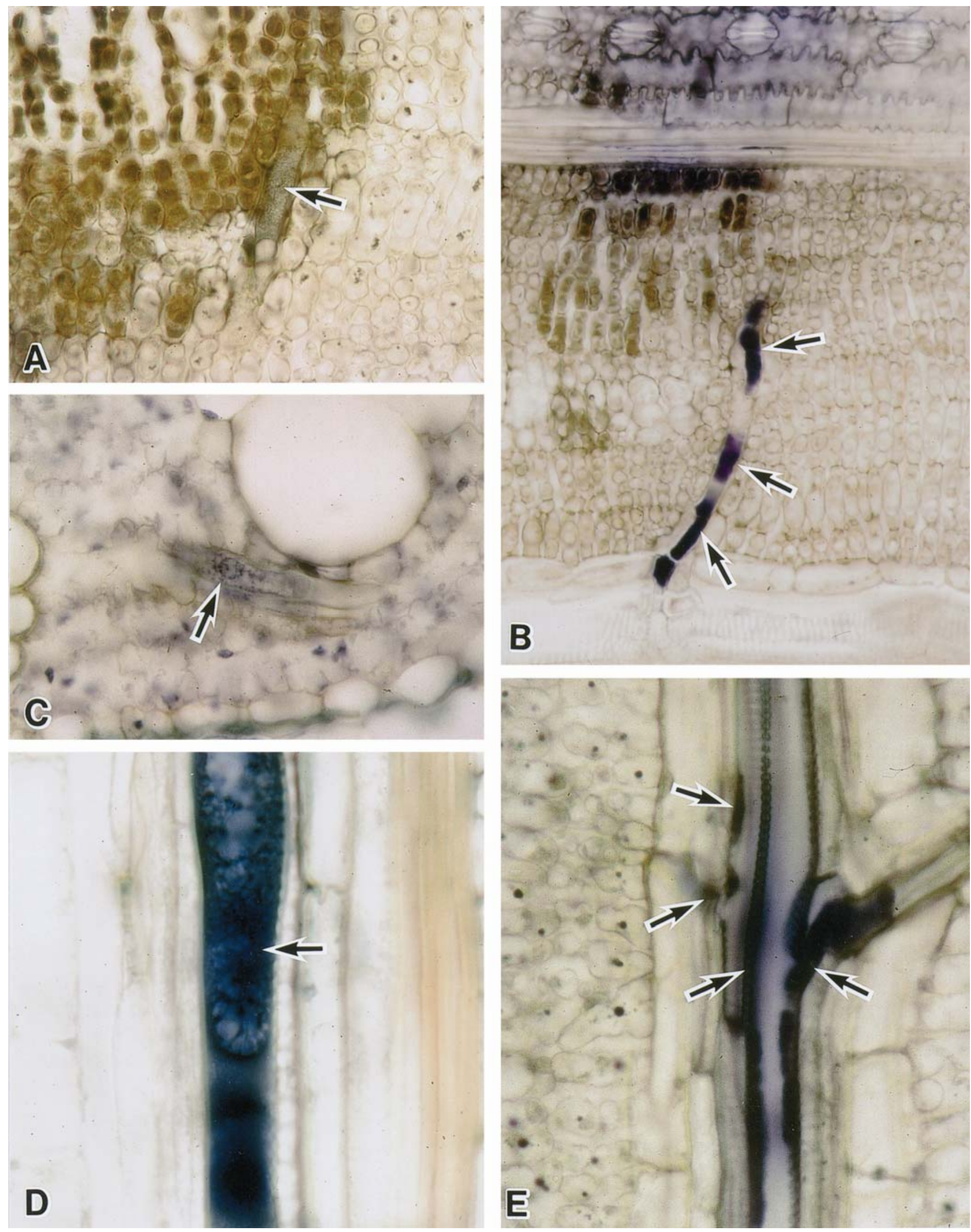

Fig. 3. Histopathology of leaves naturally infected with red stripe collected in paddy fields. A, Longitudinal section of central area of early-developing orange spot. Bacterial cells (arrow) in the vascular elements connected to the necrotic area of a wound $(\times 510)$. B, Longitudinal section through central area of an early-developing orange spot. Bacterial masses (arrows) are in xylem vessel, apparently translocated from wound area $(\times 335)$. C, Cross section of earlydeveloping orange spot with aggregates of bacterial cells (arrow) in the lumen of xylem vessel ( $\times 750)$. D, Longitudinal section of orange spot symptom with reactive materials (arrow) stained dark blue and bubble-like structure in the lumen of xylem vessel of longitudinal vascular bundle $(\times 1,050)$. E, Longitudinal section of orange spot with bacterial masses (arrows) on vessel wall of longitudinal vascular bundle $(\times 650)$. 
strands) without a bundle sheath than in longitudinal vascular bundles. They were especially frequent at the juncture of a longitudinal and a transverse vascular bundle (Fig. 2C and E). In some samples, however, they were also found in longitudinal vascular bundles. Sections parallel to the surface showed clearly the distribution of the bacterial masses (Fig. 2E).

In sections of the orange spots, many large globular granules, stained dark blue to black, appeared in the parenchyma cells (Fig. 2B). In severely affected areas, the cells became necrotic and the protoplasm was stained brown.

In the area of halos, bacterial masses were rarely observed in the vascular system or parenchyma tissues. Degraded chloroplasts were a common histological feature in tissues exhibiting halos.

In late-stage infections, orange to yellow spots enlarged very rapidly, turned necrotic, and blight symptoms developed. In the highlighted areas, the bacterial masses were widely distributed in the vascular system, more frequently in the lumina of xylem vessels. The parenchymatous tissues in the blight zones were severely affected by the bacterial infection (Fig. 2F). The parenchyma cells degenerated, and then appeared dead. None of the histological features described for diseased plants were observed in control plants.

Histological observations of red stripe symptoms in paddy fields. The histopathology of rice plants showing red stripe symptoms collected from paddy fields in Indonesia and Vietnam confirmed bacterial infection.

Bacterial masses were detected in vascular bundles in lesion areas. They were found in $100 \%$ of the samples with typical red stripe symptoms. They were not found in tissues of healthy rice leaves from the same paddy fields where the diseased samples were collected.

As in the artificially inoculated samples, the red stripe pathogen was observed to enter through stomata in the early stage of natural infection. In addition, wounds were often found in the center of red stripe lesions, and bacterial masses were found in the lumen of xylem vessels exposed or connected to the necrotic area of wounds (Fig. 3A and C).

In samples with newly developing orange spots, bacterial masses were detected in the intercellular spaces of parenchymatous tissues of the lesion area. In some cases, they were found also in the lumina of xylem vessels of vascular bundles.

Histological changes were more pronounced in naturally occurring lesions than in artificially inoculated lesions. Among naturally occurring lesions, translocation of the bacterium was much more noticeable than in artificially inoculated lesions, and accordingly the bacterial masses were more widely distributed in naturally infected leaves. Bacterial masses were fre- quently detected in longitudinal xylem vessels as well as transverse xylem vessels (Fig. 3E). In addition, the lumina of xylem vessels were, in some cases, filled with the bacterial masses. In some sections, the bacterial masses appeared as aggregates of single bacterial cells (Fig. 3B). In the lumina of longitudinal xylem vessels of large vascular bundles, however, bacterial masses in most cases attached to vessel walls (Fig. 3E). Tissues that stained blue and included bubble-like structures in response to bacterial infection were also frequently observed in the lumina of longitudinal vessel walls of large vascular bundles (Fig. 3D). In some cases, the bacterial masses were found in the vascular bundles of the halo area.

In the samples of naturally infected tissues with typical red stripe symptoms composed of orange spots and long halos, small granules that stained dark blue in parenchymatous tissues were observed. In addition, degradation of chloroplasts in tissues showing halo symptoms was more pronounced than in artificially inoculated tissues.

\section{DISCUSSION}

Although some trials have been done to examine microorganisms in red stripeaffected tissues of rice under an electron microscope, neither virus particles nor bacterial cells have been observed (O. Horino, personal communication). Mew et al. (12) also did not observe bacteria-like structures on red stripe lesions using the electron microscope.

Therefore, light microscopy was performed to detect microorganisms in the tissues infected with red stripe because with a rotary microtome whole tissues can be serially sectioned. Differential staining is another advantage of light microscopy. In Japan, Stoughton's differential staining method has been used in histopathology studies of bacterial diseases of rice $(6,7,8,17)$. The staining method was applied to detect the bacterium in naturally occurring red stripe-affected tissues as well as in artificially inoculated samples.

As a result, the bacterial masses were found in all samples with symptoms of red stripe, providing evidence that the symptoms of red stripe are caused by a bacterial infection, designated as bacterial red stripe in the first report of the disease (13). The failure to find bacterial cells in lesions of red stripe using an electron microscope is assumed to be due to the localized distribution of bacterial masses within the vascular system and parenchymatous tissues.

Several fungal species were isolated previously from samples with red stripe and have been suspected as the causal agent. In this study, mycelia and spores of these fungi were detected on the surface of red stripe lesions, not in the tissues associated with the lesions. Because the disease can be controlled with the fungicide benzimidazole, a fungus had been thought to be responsible for the disease. However, this fungicide has been shown to have antibacterial properties against the red stripe pathogen Microbacterium sp. (10).

In this study, we showed that the causal bacterium invades vascular elements through stomata and wounds. This mode of infection appears to be common among phytopathogenic coryneform bacteria, such as Clavibacter spp., in the same family, Microbacteriaceae, as the red stripe pathogen (14). The typical symptoms of red stripe are also similar to those caused by phytopathogenic coryneform bacteria, which can cause leaf spot, blight, wilt, and other symptoms (18).

Most members of phytopathogenic coryneforms require wounds to enter their hosts (5). Wounding occurs in paddy fields, most often by wind and insects. Therefore, wounds, frequently observed in red stripe samples collected in the paddy fields, are likely to be an important mode of ingress for the red stripe pathogen.

In typical vascular diseases caused by bacteria, the lumina of xylem vessels are usually filled with bacterial masses $(6,8,14,17)$. Accordingly, wilt symptoms appear to be due to the blockage of water flow in vascular systems.

In plants affected with red stripe, however, bacterial growth and distribution were not typical of bacterial vascular pathogens such as Xanthomonas oryzae pv. oryzae. The present study showed that the bacterial masses were, in many cases, tightly attached to vessel walls. The xylem fluid contains the lowest concentration of organic compounds (sources of available energy) of any plant tissue $(4,15)$.

One possible reason for the efficient pathogenesis of the red stripe pathogen is that it enters vascular tissues of rice leaves and produces a toxin. Evidence for a toxin is expressed in the typical lesion of red stripe, accompanied by a long halo running lengthwise from the spot upward. In fact, many of the members of Microbacteriaceae such as Clavibacter are thought to cause diseases by the elaboration of specific chemical compounds, including toxins (5). Some of them cause symptoms similar to red stripe of rice such as spot, blight, and wilt (18).

Based on this histological study, as well as on pathogenicity tests (11), red stripe is caused by a bacterial infection, and the mode of infection of the bacterium appears to be very similar to that of Clavibacter species.

\section{ACKNOWLEDGMENTS}

I thank Beth Hazen for critical review of this manuscript. I also thank S. Subandiyah, Gadjamada University, Indonesia and T. Noda for their assistance in collection of samples, and K. Shitomi for her technical assistance.

\section{LITERATURE CITED}

1. Collins, M. D., and Bradbury, J. F. 1992. The genera Agromyces, Aureobacterium, Clavibacter, Curtobacterium, and Microbacterium. 
Pages 1355-1368 in: The Prokaryotes, Vol. 2. A. Balows, H. G. Trueper, M. Dworkin, W. Harder, and K. H. Schleifer, eds. SpringerVerlag, Berlin, Germany.

2. Du, P. V., Lan, N. T. P., and Dinh, H. D. 1991. Red stripe: A new reported disease of rice in Vietnam. Int. Rice Res. Newsl. 16:25.

3. Du, P. V., Lan, N. T. P., Dinh, H. D., Sau, T. T., and Ba, D. X. 1991. Field evaluation to control 'red stripe', a new rice disease in Vietnam. Int. Rice Res. Newsl.16:25.

4. Hopkins, D. L. 1989. Xylella fastidiosa: A xylem-limited bacterial pathogen of plants. Annu. Rev. Phytopathol. 27:271-290.

5. Kado, C. I. 1992. Plant pathogenic bacteria Pages 659-674 in: The Prokaryotes, Vol. 2. A. Balows, H. G. Trueper, M. Dworkin, W. Harder, and K. H. Schleifer, eds. SpringerVerlag, Berlin, Germany.

6. Kaku, H. 1993. Infection types in riceXanthomonas campestris pv. oryzae interaction. JARQ 27:81-87.

7. Kaku, H., and Hori, M. 1977. Browning reaction in rice plant tissues induced by Xanthomonas oryzae. Ann. Phytopathol. Soc. Jpn. 43:487-490.

8. Kaku, H., and Kimura, T. 1978. Reaction types of rice cultivars to strains of Xanthomonas oryzae. Bull. Chugoku Natl. Agric. Exp. Stn. E13:17-43.

9. Kaku, H., and Ochiai, H. 2001. The causal bacterium of red stripe of rice. Pages 249-251 in: Plant Pathogenic Bacteria. Solke H. De Boer, ed. Kluwer Academic Publishers, Dordrecht, Netherlands.

10. Kaku, H., Shiraishi, M., and Ochiai, H. 2001. Infection mode of the causal bacterium of red stripe of rice (Microbacterium sp.) and its sensitivity to Benomyl. (Abstr.) Jpn. J. Phytopatol. 67(2):203.

11. Kaku, H., Subandiyah, S., and Ochiai, H. 2000. Red stripe of rice is caused by a bacterium Microbacterium sp. J. Gen. Plant Pathol. 66:149-152.

12. Mew, T. W., Castilla, N. P., Elazegi, F. A., and Vera Cruz, C. M. 2001. The etiology of red stripe of rice: Current status and future directions. Int. Rice Res. Notes 26:4-10.

13. Mogi, S., Sugandhi, Z., and Baskoro, S. 1988. A new discovered disease (bacterial red stripe) on rice at Indonesia, its symptom and distribution. (Abstr.) Int. Congr. Plant Pathol. Kyoto, Japan. P388.

14. Nelson, P. E., and Dickey, R. S. 1970. Histopathology of plants infected with vascular bacterial pathogens. Annu. Rev.
Phyopathol. 8:259-280.

15. Purcel, A. H., and Hopkins, D. L. 1996. Fastidious xylem-limited bacterial plant pathogens. Annu. Rev. Phytopathol. 34:131-151.

16. Stoughton, R. H. 1930. Thionin and orange G for the differential staining of bacteria and fungi in plant tissue. Ann. Appl. Biol. 17:162164.

17. Tabei, H. 1977. Anatomocal studies of rice plant affected with bacterial leaf blight, Xanthomonas oryzae (Uyeda et Ishiyama) Dowson. Bull. Kyushu Agric. Exp. Stn. 19:193257.

18. Vidaver, A. K. 1982. The plant pathogenic corynebacteria. Annu. Rev. Microbiol. 36:495517.

19. Vihn, M. T. 1997. Etiological studies on the yellow leaf syndrome of rice (Oryza sativa $\mathrm{L}$.). M.S. thesis. University of the Philippines Los Banos, College, Laguna. p. 77.

20. Wakimoto, S., Kim, P. V., Thuy, T. T. T., Tsuno, K., Kardin, M. K., Hartini, R. H., Surang, S., Sunetra, P., Nipalnit, N., Negishi, H., and Suyama, K. 1998. Micro-fungus closely associated with the lesions of red stripe disease of rice. Int. Congr. Plant Pathol. Abstracts of papers. Vol. 3, Edinburgh, Scotland. P3-6-11. 